\title{
BIBLIOGRAPHIE / BIBLIOGRAPHY
}

\section{RECHT UND ENTWICKLUNG ALLGEMEIN / LAW AND DEVELOPMENT IN GENERAL}

[Governance in developing countries]- In: The Journal of Development Studies (Abingdon), 50 (June 2014) 6. S. 773-854

Hammergren, Linn A.: Justice reform and development: rethinking donor assistance to developing and transition countries / Linn A. Hammergren. - London ...: Routledge, 2014 - XI, 265S., Tab., Lit. S. 239-257, Lit. Hinw. (Law, Development and Globalization) ISBN 978-0-315-81631-9; 978-0-415-73992-4

Joanis, Marcelin: Shared accountability and partial decentralization in local public good provision / Marcelin Joanis. - In: Journal of Development Economics (Amsterdam), 107 (March 2014). S. 28-37

Politicising democracy: the new local politics of democratisation / John Harris ... (eds.). - first publ. 2004, paperback ed. 2013 - Basingstoke: Palgrave Macmillan, 2013 - 253S., Lit. Hinw., Reg. (International Political Economy Series) ISBN 978-1-137-35519-5; 978-1-4039-3481-9

Regilme Jr., Salvador Santino F.: The social science of human rights: the need for a "second image reversed"? / Salvador Santino F. Regilme Jr., - In: Third World Quarterly (Egham), 35 (2014) 8. S. 1390-1405

\section{AFRIKA / AFRICA}

Abbink, Jon: Religious freedom and the political order: the Ethiopian "secular state" and the containment of Muslim identity politics / Jon Abbink. - In: Journal of Eastern African Studies (Nairobi), 8 (August 2014) 3. S. 346-365, Lit. S. 364-365, Lit. Hinw. S. 362-364

Anders, Gerhard: Transitional justice, states of emergency and business as usual in Sierra Leone / Gerhard Anders. - In: Development and Change (Oxford), 45 (May 2014) 3. S. 524-542, Lit. S. 540-541, Lit. Hinw.

Armstrong, Kimberley: Justice without peace?: International justice and conflict resolution in northern Uganda / Kimberley Armstrong. - In: Development and Change (Oxford), 45 (May 2014) 3. S. 589-607, Lit. S. 606-607, Lit. Hinw.

Bartholain, Milena: Formal demokratische Elemente in Parteiengesetzen: autoritäre und hybride Regime Subsahara-Afrikas im Vergleich / Milena Bartholain. - Berlin: Stiftung Wissenschaft und Politik, 2014 - 32 S., Tab., Lit. Hinw. - (SWP-Working Paper; FG6-WP 2014/01)

Bonthuys, Elsje: Domestic violence and gendered socio-economic rights: an agenda for research and activism? / Elsje Bonthuys. - In: South African Journal on Human Rights (Lansdowne), 30 (Part 1) 2014. S. 111-133, Lit. Hinw.

Branch, Adam: The violence of peace: ethnojustice in northern Uganda / Adam Branch. - In: Development and Change (Oxford), 45 (May 2014) 3. S. 608-630, Lit. S. 629-630, Lit. Hinw. 
Caparini, Marina: Extending state authority in Liberia: the Gbarnga justice and security hub / Marina Caparini. - Oslo: Norwegian Institute of International Affairs, 2014 - 55S. - (NUPI Report; 5, 2014) ISSN 1894-650X

Chiviru, Theophilous: Socio-economic rights in Zimbabwe's new constitution / Theophilous Chiviru. - In: Strategic Review for Southern Africa (Pretoria), 36 (May 2014) 1. S. 111-119, Lit. S. 119

Claassens, Aninka: Denying ownership and equal cictizenship: continuities in the state's use of law and "custom", 1913-2013 / Aninka Claassens. - In: Journal of Southern African Studies (Basingstoke), 40 (August 2014) 4. S. 761-779, Lit. Hinw.

La constitution béninoise du 11 décembre 1990: un modèle pour l'Afrique? ; Mélanges en l'honneur de Maurice Ahanhanzo-Glélé / études coordonnées par Frédéric Joël Aïvo. - Paris: L'Harmattan, 2014 - 798S., Ill., Lit. Hinw. (Etudes africaines) ISBN 978-2-343-03682-3

Decker, Alicia C.; Arrington, Andrea L.: Africanizing democracies: 1980 - present / Alice C. Decker; Andrea L. Arrington. - New York/N.Y. ...: Oxford Univ. Press, 2015 [i.e.2014] - XII, 100S., Ill., Kt., Reg., Lit. Hinw. (African World Histories) ISBN 978-0-19-991539-2

Eltringham, Nigel: 'When we walk out, what was it all about?': views on new beginnings from within the International Criminal Tribunal for Rwanda / Nigel Eltringham. - In: Development and Change (Oxford), 45 (May 2014) 3. S. 543-564, Lit. S. 561-564, Lit. Hinw.

Engels, Bettina: Missachtung grundlegender Rechte als Konfliktursache: Auseinandersetzungen um Staatsbürgerschaft, Wahl- und Landrecht und der Bürgerkrieg in der Côte d'Ivoire / Bettina Engels. - In: Zeitschrift für Menschenrechte (Schwalbach/Taunus), 8 (2014) 1. S. 64-76

Fresia, Marion: Performing repatriation?: The role of refugee aid in shaping new beginnings in Mauritania / Marion Fresia. - In: Development and Change (Oxford), 45 (May 2014) 3. S. 434-457, Lit. S. 455-457, Lit. Hinw.

Goetze, Catherine: Statebuilding in a vacuum: Sierra Leone and the missing international political economy of civil wars / Catherine Goetze. - In: The post-conflict enviroment / Daniel Bertrand Monk... (eds.) - Ann Arbor/Mich.: Univ. of Michigan Press, 2014. S. 25-67, Lit. S. 57-67 ISBN 978-0-472-05223-3; 978-0-472-07223-1; 978-0-472-12039-0

Goodfellow, Tom: Legal manoeuvres and violence: law making, protest and semi-authoritarianism in Uganda / Tom Goodfellow. - In: Development and Change (Oxford ...), 45 (July 2014) 4. S. $753-776$

Grøner Krogstad, Erlend: Local ownership as dependence management: inviting the coloniser back / Erlend Grøner Krogstad. - In: Journal of Intervention and Statebuilding (Abingdon), 8 (JuneSeptember 2014) 2-3. S. 105-125

Hay, Michelle: A tangled past: land settlement, removals and restitution in Letaba District, 19002013 / Michelle Hay. - In: Journal of Southern African Studies (Basingstoke), 40 (August 2014) 4. S. 745-760, Kt., Lit. Hinw.

Höhn, Sabine: New start or false start?: the ICC and electoral violence in Kenya / Sabine Höhn. - In: Development and Change (Oxford), 45 (May 2014) 3. S. 565-588, Lit. S. 584-588, Lit. Hinw. 
King, Sophie: Cultivating political capabilities among Ugandan smallholders: good governance or popular organisation building? / Sophie King. - Manchster: Brooks World Poverty Institute, 2014 30S., graph. Darst., Tab., Lit. S. 24-29, Lit. Hinw. - (BWPI Working Paper; 193) ISBN 978-1-909336-11-7

Matlosa, Khabele: Pan-Africanism, the African peer review mechanism and the African Charter on Democracy, Elections and Governance: what does the future hold? / Khabele Matlosa. - Braamfontein: South African Institute of International Affairs, 2014 - 33S., Tab. - (Occasional Paper / South African Institute of International Affairs; 190) (Governance and APRM Programme)

Moore, David: Zimbabwe's democracy in the wake of the 2013 election: contemporary and historical perspectives / David Moore. - In: Strategic Review for Southern Africa (Pretoria), 36 (May 2014) 1. S. 47-71, Lit. S. 67-71

Mueller, Susanne D.: Kenya and the International Criminal Court (ICC): politics, the election and the law / Susanne D. Mueller. - In: Journal of Eastern African Studies (Nairobi), 8 (February 2014) 1. S. 25-42, Lit., Lit. Hinw.

Muller, Gustav: On considering alternative accommodation and the rights and needs of vulnerable people / Gustav Muller. - In: South African Journal on Human Rights (Lansdowne), 30 (Part 1) 2014. S. 41-62, Lit. Hinw.

Ochieng' Opalo, Kennedy: The long road to institutionalization: the Kenyan Parliament and the 2013 elections / Kennedy Opalo. - In: Journal of Eastern African Studies (Nairobi), 8 (February 2014) 1. S. 63-77, graph. Darst., Lit., Lit. Hinw.

Omotola, J. Shola: The African Union and the promotion of democratic values in Africa: an electoral perspective / J Shola Omotola. - Braamfontein: South African Institute of International Affairs, 2014 - 38S., Tab. - (Occasional Paper / South African Institute of International Affairs; 185)

Ouédraogo, Boureima: Droit, démocratie et développement en Afrique: un parfum de jasmin souffle sur le Burkina Faso / Boureima N. Ouédraogo. - Paris: L'Harmattan, 2014 - 157S., Lit. Hinw. (Etudes africaines) ISBN 978-2-343-02229-1

Oyewo, Oyelowo: Constitutional law in Nigeria / Oyelowo Oyewo. - Alphen aan den Rijn: Kluwer Law International, 2013 - 164S., Tab., Reg., Lit. Hinw. ISBN 978-90-411-4592-5

Report of the Secretary-General on the restoration of and respect for constitutional order in Guinea-Bissau/ United Nations Security Council. - New York/N.Y., 2014 - 10S.

Saylor, Ryan: State building in boom times: commodities and coalitions in Latin America and Africa / Ryan Saylor. - Oxford ...: Oxford Univ. Press, 2014 - X, 244S., Tab., Lit. S. 217-237, Lit. Hinw. ISBN 978-0-19-936495-4

Schönteich, Martin: Strengthening prosecutorial accountability in South Africa / Martin Schönteich. Pretoria: Institute for Security Studies, 2014 - 23S., Lit. Hinw. - (ISS Papers; 255)

Steinberg, Jonny: Policing, state power, and the transition from apartheid to democracy: a new perspective / Jonny Steinberg. - In: African Affairs (Oxford), 113 (April 2014) 451. S. 173-191

Voors, Maarten; Bulte, Erwin H.: Conflict and the evolution of institutions: unbundling institutions at the local level in Burundi / Maarten J Voors \& Erwin H Bulte. - In: Journal of Peace Research (London), 51 (July 2014) 4. S. 455-469, Tab., Lit. S. 467-469 
Wibabara, Charity: Gacaca courts versus the International Criminal Tribunal for Rwanda and national courts: lessons to learn from the Rwandan justice approaches to genocide / Charity Wibabara. Baden-Baden: Nomos, 2014 - 298S., Tab., Lit. S. 263-298, Lit. Hinw. - (Schriften zum internationalen und europäischen Strafrecht; 13) - Zugl.: Kapstadt, Univ. of the Western Cape, Berlin, Humboldt-Univ., Diss., 2013 ISBN 978-3-7272-7744-3; 978-3-8452-5360-2; 978-3-8487-1247-2

Zenker, Olaf: New law against an old state: land restitution as a transition to justice in post-apartheid South Africa? / Olaf Zenker. - In: Development and Change (Oxford), 45 (May 2014) 3. S. 502 523, Lit. S. 521-523, Lit. Hinw.

\section{ASIEN / ASIA}

20th by 2020: Bhutan's drive for improved governance / Asian Development Bank. - Manila: ADB, 2014 - xi, 74S., zahlr. graph. Darst., Tab. ISBN 978-92-9254-620-5 (Print); 978-92-9254-621-2 (eISBN)

André, Paul: Can North Korea follow the "Chinese way?": The tricky case of constitutionalizing a socialist regime / Paul André. - In: The Journal of East Asian Affairs (Seoul), 28 (Spring-Summer 2014) 1. S. 53-84, graph. Darst., Lit. S. 83-84

Bringing the Khmer Rouge to justice: prosecuting mass violence before the Cambodian courts / ed. by Jaya Ramji .... - Lewiston/N.Y. ...: Mellen, 2005 - V,441S., Reg., Lit. Hinw. - (Criminology Studies; 27) ISBN 0-7734-5994-4

Burch Elias, Stella: Comprehensive immigration reform(s): immigration regulation beyond our borders / Stella Burch Elias. - In: The Yale Journal of International Law (New Haven/Conn.), 39 (Winter 2014) 1. S.[37]-86

Egreteau, Renaud: Legislators in Myanmar's first “post-junta" national parliament (2010-2015): a sociological analysis / Renaud Egreteau. - In: Journal of Current Southeast Asian Affairs (Hamburg), 33 (2014) 2. S. 91-124, zahlr. graph. Darst., Tab., Anh., Lit. Hinw.

Holbig, Heike: China's unwritten constitution: ideological implications of a "non-ideological" approach / Heike Holbig. - In: Asien (Hamburg), (Juli 2014) 132. S. 53-59

Julie, Kumiko K.: Problems in the implementation of Chinese human rights obligations $=$ The problems of Chinese labor / Kumiko K. Julie. - Bloomington/Ind.: Xlibris Corp., 2010 - 103S., Reg., Lit. S. 87-93 ISBN 978-1-4500-5525-3; 978-1-4500-5526-0

Klein, Katheryn M.: Bringing the Khmer Rouge to justice: the challenges and risks facing the joint tribunal in Cambodia / Katheryn M. Klein. - In: Journal of International Human Rights (Chicago), 4 (Spring 2006) 3. S. 549-566, Lit.-Hinw.

Manning, Peter: Justice, reconciliation and memorial politics in Cambodia / Peter Manning. - London: The London School of Economics and Political Science, 2014 - 245S., Ill., Kt., Lit. S. 232-245, Lit.-Hinw. - Zugl.: London, Univ., Diss., 2014

Mitra, Durba; Satish, Mrinal: Testing chastity, evidencing rape: impact of medical jurisprudence on rape adjudication in India / Durba Mitra ; Mrinal Satish. - In: Economic and Political Weekly (Mumbai), 49 (October 11, 2014) 41. S. 51-58, Lit., Lit. Hinw. 
Norpoth, Johannes; Groß, Lukas; Aktar, Rahima: Child labour in Bangladesh: an analysis of gaps and weaknesses of the existing legal framework / Johannes Norpoth, Lukas Groß, and Rahima Aktar. - Bochum: Institut für Entwicklungsforschung und Entwicklungspolitik der Ruhr-Universität Bochum, 2014 - III,37S., Lit., Lit. Hinw., Internet-Hinw. - (IEE Working Papers; 204) ISBN 978-3-927276-90-1

Ortmann, Stephan: The significance of by-elections for political change in Singapore's authoritarian regime / Stephan Ortmann. - In: Asian Survey (Berkeley/Cal.), 54 (July-August 2014) 4. S. $725-748$

Pham, Tien; Vu, Truong: The quest to be a "human rights promoter": the European Union and the case of Vietnam / Tien Pham and Vu Truong. - In: Asien (Hamburg), (April 2014) 131. S. 25-45

Robertson, Jennifer: Human rights vs. robot rights: forecast from Japan / Jennifer Robertson. - In: Critical Asian Studies (Cedar/Mich.), 46 (December 2014) 4. S. 571-598

Schwemann, Bengt: Japans Beitritt zum Haager Übereinkommen über die zivilrechtlichen Aspekte internationaler Kindesentführung / Bengt Schwemann. - Frankfurt am Main: Interdisziplinäres Zentrum für Ostasienstudien, 2014 - 38S., Lit. S. 35-38, Lit.-Hinw. - (Frankfurt Working Papers on East Asia; 9)

Scott, Ian: Political scandals and the accountability of the Chief Executive in Hong Kong / Ian Scott. In: Asian Survey (Berkeley/Cal.), 54 (September-October 2014) 5. S. $966-986$

Smith, Claire Q.: Illiberal peace-building in hybrid political orders: managing violence during Indonesia's contested political transition / Claire Q. Smith. - In: Third World Quarterly (Egham), 35 (2014) 8. S. 1509-1528

Solaiman, S. M.; Ali, Abu Noman Mohammad Atahar: Extensive food adulteration in Bangladesh: a violation of fundamental human rights and the state's binding obligations / S. M. Solaiman and Abu Noman Mohammad Atahar Ali. - In: Journal of Asian and African Studies (London), 49 (October 2014) 5. S. 617-629, Tab., Lit. Hinw.

Suh, Bo-hyuk: Beyond silence and blaming: revisiting South Korea's role in North Korean human rights / Bo-hyuk Suh. - In: Asian Perspective (Boulder/Colo.), 37 (January-March 2013) 1. S. $77-97$

Törnquist, Olle: Assessing dynamics of democratisation: transformative politics, new institutions, and the case of Indonesia / by Olle Törnquist. - New York/N.Y.: Palgrave Macmillan, 2013 - XVIII, 302S., Anh. S. 125-274, Reg., Lit., Lit. Hinw. ISBN 978-1-137-36934-5

Tsai, Wen-hsuan; Dean, Nicola R.: Experimentation under hierarchy in local conditions: cases of political reform in Guangdong and Sichuan, China / Wen-Hsuan Tsai and Nicola Dean. - In: The China Quarterly (London), (June 2014) 218. S. 339-358

\section{LATEINAMERIKA / LATIN AMERICA}

Barrera, Anna: Promoviendo la justicia propia dejando atrás un trato indigno: resultados de un estudio sobre cambios en sistemas legales indígenas y campesinos en seis localidades andinas / Anna Barrera Vivero. - Quito: Andinagraph, 2014 - 63S., Ill., Lit. Hinw. 
Basabe Serrano, Santiago; Valdivieso Kastner, Pablo: ¿Cómo van los jueces?: Un modelo integral de elección judicial aplicado a la Corte Suprema del Ecuador / Santiago Basabe-Serrano ; Pablo Valdivieso Kastner. - In: Revista de Estudios Politicos (Madrid), (abril-junio 2014) 164. S. 183-209, Tab., Lit. Hinw., Lit. S. 205-208

Carranza-Franco, Francy: A sub-national approach to state-building and security: the role of municipal institutions in Colombia's DDR process / Francy Carranza-Franco. - In: Conflict, Security and Development (London), 14 (July 2014) 3. S.[245]-274, Lit. S. 270-274, Lit. Hinw. 267-270

Davis, Jeffrey: Seeking human rights justice in Latin America: truth, extra-territorial courts, and the process of justice / Jeffrey Davis. - Cambridge: Cambridge Univ. Press, 2014 - XI, 239S., Ill., Tab., Kt., Reg., Lit. Hinw. ISBN 978-0-521-51436-1

Direitos humanos no Brasil 2013: relatório da Rede Social de Justiça e Direitos Humanos / Daniela Stefano ... (orgs.). Rede Social de Justiça e Direitos Humanos. - São Paulo: Rede Social de Justiça e Direitos Humanos, 2013 - 180S., Ill., Kt., graph. Darst., Tab., Lit. Hinw.

Hoffmann, Bert: The international dimension of authoritarian regime legitimation: insights from the Cuban case / Bert Hoffmann. - [Vorveröffentlichung] - Basingstoke ...: Palgrave Macmillan, 2014 - o. P. - (Journal of International Relations and Development; 18.06.2014)

Krennerich, Michael: Gewalt und Menschenrechte in Lateinamerika / Michael Krennerich. - In: Zeitschrift für Menschenrechte (Schwalbach/Taunus), 8 (2014) 1. S. 184-202

Kretschmer, Regine: Das Massaker von Marina Kue (Curuguaty): Landkonflikte und Verfolgung von campesinos in Paraguay / Regine Kretschmer. - In: Zeitschrift für Menschenrechte (Schwalbach/ Taunus), 8 (2014) 1. S. 78-87

Monje, José Antonio: Cooperación internacional, descentralización y participación ciudadana: la gestión de la asistencia oficial para el desarrollo desde los gobiernos autónomos descentralizados en el Ecuador / José Antonio Monje. - Santiago de Chile: Comisión Económica para América Latina y el Caribe, 2014 - 29S., graph. Darst., Tab., Lit. S. 29 (Documento de Proyecto / Comisión Económica para América Latina y el Caribe)

Monroy García, Juan José: De la insurrección a la transición a la democracia en Centroamérica $=$ los casos del Salvador, Guatemala y Nicaragua / Juan José Monroy García. - Toluca: Univ. Autónoma del Estado de México, 2013 - 155S., Lit. S. 149-155 ISBN 978-607-422-422-1

Núñez de Escorcia, Vilma: ¿Por qué no ha habido en Nicaragua justicia transicional?: ¿Sería posible aquí una Comisión de la Verdad? / Vilma Núñez de Escorcia. - In: Envío (Ed. Española) (Managua), 33 (junio 2014) 387. S. 24-33

Pasqualucci, Jo M.: The practice and procedure of the Inter-American Court of Human Rights / Jo M. Pasqualucci. - 2nd. ed. - New York/N.Y.: Cambridge Univ. Press, 2014 - 1,410S., Lit. Hinw., Lit. S. 389-400 ISBN 978-1-107-69190-2

Pousadela, Inés María: What works in the criminal justice system (and what doesn't): a 2000-11 update on policing, courts, and corrections / Inés M. Pousadela. - Washington/D.C.: Inter-American Development Bank, 2014 - 17S., Tab. - (Policy Brief / Inter-American Development Bank; IDBPB-227) 
Saylor, Ryan: State building in boom times: commodities and coalitions in Latin America and Africa / Ryan Saylor. - Oxford ...: Oxford Univ. Press, 2014 - X,244S., Tab., Lit. S. 217-237, Lit. Hinw. ISBN 978-0-19-936495-4

Schilling-Vacaflor del Carpio, Almut: Formas de discriminación y asimetrías de poder en la Asamblea Constituyente boliviana / Almut Schilling-Vacaflor. - In: El primer gobierno de Evo Morales: un balance retrospectivo. / Tanja Ernst; Stefan Schmalz (eds.). - La Paz: Plural, 2012. S. 93-107, Lit. Hinw., Lit. S. 105-107 ISBN 978-99954-1-432-0

Tiede, Lydia Brashear; Ponce, Aldo Fernando: Evaluating theories of decision-making on the Peruvian Constitutional Tribunal / Lydia Brashear Tiede ; Aldo Fernando Ponce. - In: Journal of Politics in Latin America (Hamburg), 6 (August 2014) 2. S. 139-164, Tab., Lit. Hinw., Lit. S. 151-155

Wright, Claire; Soliz Landivar, Ana: De instrumentos militares de la dictadura a instrumentos políticos de la democracia: regímenes de excepción en Bolivia 2000-2010 / Claire Wright; Ana Soliz Landívar. - In: Revista de Ciencia Política (Santiago de Chile) (Santiago de Chile), 51 (2013) 1. S. 31-59

Yvypóra Derécho Paraguáipe - Derechos humanos en Paraguay 2013/ Enrique Gauto Bozzano (coord.). Coordinadora de Derechos Humanos del Paraguay. - Asunción: Coordinadora de Derechos Humanos del Paraguay, 2013 - 619S., Tab., Lit. Hinw.

\section{NAHER UND MITTLERER OSTEN / NEAR AND MIDDLE EAST}

Ammour, Laurence Aïda: The legislative environment of the Algerian civil society / Laurence Aïda Ammour. - Dakar, 2012 - 56S., Lit. Hinw. For publication in: Bhekinkosi Moyo (dir.), Governing the Public Sphere: Civil Society Regulation in North Africa, Vol. II, Trustafrica (Dakar) (forthcoming)

---L'environnement législatif de la société civile en Algérie / Laurence Aïda Ammour. - Bordeaux ..., 2011 - 55S., Tab., Lit. S. 48-53 English translation for publication in: Bhekinkosi Moyo (dir.),Governing the Public Sphere: Civil Society Regulation in North Africa, Vol. II, Trustafrica (Dakar) (forthcoming)

The Arab Spring: will it lead to democratic transitions? / edited by Clement Henry .... - New York/ N.Y.: Palgrave Macmillan, 2013 - 317S., Tab., Reg., Anh., Lit. Hinw. ISBN 978-1-137-34402-1; 978-1-137-34403-8

Bank, André; Richter, Thomas; Sunik, Anna: Long-term monarchical survival in the Middle East: a configurational comparison, 1945-2012 / André Bank, Thomas Richter and Anna Sunik. - [Vorveröffentlichung] - Abingdon: Routledge, 2013 - 22S., Tab., Lit. S. 20-22, Lit. Hinw. - (Democratization (Abingdon); 20.12.2013) Außerdem erschienen: GIGA German Institute of Global and Area Studies. - Hamburg: GIGA, 2013 (GIGA Working Papers -- No 215)

Bassiouni, M. Cherif: Egypt in transition: the third republic / by M. Cherif Bassiouni. - In: Prism / National Defense University (Washington/D.C.), 4 (2014) 4. S. 3-20, Ill., Lit. Hinw.

Boose, Jason William: Democratization and civil society: Libya, Tunisia and the Arab Spring / Jason William Boose. - In: International Journal of Social Science and Humanity (Singapore), 2 (July 2012) 4. S. 310-315, Lit. S. 315 
Charrad, Mounira Maya; Zarrugh, Amina: Equal or complementary?: Women in the new Tunisian Constitution after the Arab Spring / Mounira M. Charrad and Amina Zarrugh. - In: The Journal of North African Studies (London), 19 (March 2014) 2. S. 230-243

Cheriet, Boutheina: The Arab Spring exception: Algeria's political ambiguities and citizenship rights / Boutheina Cheriet. - In: The Journal of North African Studies (London), 19 (March 2014) 2. S. $143-156$

Coburn, Noah; Larson, Anna: Derailing democracy in Afghanistan: elections in an unstable political landscape / Noah Coburn and Anna Larson. - New York/N.Y.: Columbia Univ. Press, 2014 - XVIII, 284S., Ill., Reg., Lit. S. 253-262 ISBN 978-0-231-16620-1

Erakat, Noura: Humanitarian law and operation protective edge: a survey of violations and remedies / by Noura Erakat. - Oslo: Norwegian Peacebuilding Resource Centre, 2014 - 4S. (Expert Analysis / Norwegian Peacebuilding Resource Centre)

Ethnic cleansing on a historic scale: Islamic State's systematic targeting of minorities in Northern Iraq / Amnesty International. - London, 2014 - 28S., Ill., Lit. Hinw.

Francis, Sahar: Status of Palestinian prisoners in international humanitarian law / Sahar Francis. - In: Journal of Palestine Studies (Berkeley/Cal.), 43 (Summer 2013) 4/172. S.39-48, Lit. Hinw. S. $45-48$

Freedom of religion: a human rights-based approach to discrimination against religious minorities in the Palestinian Authority / Jerusalem Institute of Justice. - Jerusalem: JIJ, 2014 - 30S., Kt., Tab., Lit. Hinw.

Güçtürk, Yavuz: The loss of humanity = the human rights dimension of the civil war in Syria / Yavuz Güçtürk. - 1st publ. - Ankara: SETA - Foundation for Political, Economic and Social Research, 2014 - 102S. - (SETA Publications; 36) ISBN 978-605-4023-39-4

The human cost of the fortress Europe: human rights violations against migrants and refugees at Europe's borders / Amnesty International. - 1st publ. - London, 2014 - 54S., Ill., graph. Darst., Tab.

Jeursen, Thijs; Borgh, Chris van der: Security provision after regime change: local militias and political entities in post-Qaddafi Tripoli / Thijs Jeursen and Chris van der Borgh. - In: Journal of Intervention and Statebuilding (Abingdon), 8 (June-September 2014) 2-3. S. 173-191

Josua, Maria; Edel, Mirjam: To repress or not to repress: regime survival strategies in the Arab Spring / Maria Josua and Mirjam Edel. - [Vorveröffentlichung] - London ...: Taylor \& Francis S. 1-21 - (Terrorism and Political Violence; 12.03.2014)

Kattan, Victor: Palestine and the International Criminal Court / by Victor Kattan. - London: European Council on Foreign Relations, 2014 - ca. 3S.

Khamlichi, Ahmed: The relationship between religion and the state: the institution of 'Commandment of the Faithful' in Morocco / Ahmed Al Khamlichi. - In: Contemporary Arab Affairs (London ...), 7 (January-March 2014) 1. S. 54-81, Lit. S. 80-81, Lit. Hinw. S. 76-80

Kurban, Dilek; Gülalp, Haldun: A complicated affair: Turkey's Kurds and the European Court of Human Rights / Dilek Kurban and Haldun Gülalp. - In: The European Court of Human Rights: implementing Strasbourg's judgments on domestic policy / ed. by Dia Anagnostou. - Edinburgh: Edinburgh Univ. Press, 2013. S.[166]-187, Lit. S. 182-187 ISBN 978-0-7486-7057-4 
Kuru, Ahmet T.: Authoritarianism and democracy in muslim countries: rentier states and regional diffusion / Ahmet T. Kuru. - In: Political Science Quarterly (New York/N.Y.), 129 (Fall 2014) 3. S. $399-427$

Liceras, Juan Soroeta: International law and the Western Sahara conflict / Juan Soroeta Liceras. Oisterwijk: Wolf Legal Publishers, 2014 - 327S., Lit. S. 285-327, Lit. Hinw. ISBN 978-94-6240-137-2; 978-94-6240-139-6

Muslim secular democracy: voices from within / edited by Lily Zubaidah Rahim. - New York/N.Y.: Palgrave Macmillan, 2013 - XIII, 284S. graph. Darst. Tab., Reg, Lit., Lit. Hinw. ISBN 978-1-137-28204-0

Olimova, Saodat Kuzuevna; Olimov, Muzaffar: Public opinion, democracy, and authoritarianism in Central Asia / Saodat Olimova ; Muzaffar Olimov. - In: Central Asia and the Caucasus (Luleå), 15 (2014) 2. S. 142-160

Pace, Michelle: The EU's interpretation of the 'Arab uprisings': understanding the different visions about democratic change in EU-MENA relations; JCMS annual lecture 2012 / Michelle Pace. - In: Journal of Common Market Studies (Oxford), 52 (September 2014) 5. S. 969-984

Pickard, Duncan: Prospects for implementing democracy in Tunisia / Duncan Pickard. - In: Mediterranean Politics (London), 19 (July 2014) 2. S. 259-264

Regional study: The right to freedom of assembly in the Euro-Mediterranean region, part 1: legislation review / Euro-Mediterranean Human Rights Network. Helena Sola Martín .... - Copenhagen: EMHRN, 2013 - 192S. Lit. Hinw., Lit. S. 186-189 ISBN 978-87-92990-16-7

Report of the independent international commission of inquiry on the Syrian Arab Republic: Human Rights Council, twenty-seventh session, agenda item 4 - New York/N.Y., 2014 - 45S., Kt., Lit. Hinw.

Sayed Ahmad, Refat: Religion and the state in Turkey and Iran: a comparative overview / Refat Sayed Ahmad. - In: Contemporary Arab Affairs (London ...), 7 (January-March 2014) 1. S. 36-53, Lit. S. 52-53, Lit. Hinw. S. 52

Seufert, Günter: Erdoğans "Neue Türkei": die Restauration des autoritären Staates im Namen der Demokratie / Günter Seufert. - Berlin: Stiftung Wissenschaft und Politik, 2014 - 8S. - (SWP-aktuell; 60/2014) ISSN 1611-6364

---Erdoğans "New Turkey": restoring the authoritarian state in the name of democracy / Günter Seufert. Translation by Meredith Dale. - Berlin: Stiftung Wissenschaft und Politik, 2014 - 7S. - (SWP Comments; 44/2014) Außerdem erschienen u.d.T.: Erdoğans "Neue Türkei". - Berlin: SWP, 2014. - (SWP-aktuell -- 60/2014) ISSN 1861-1761

Storm, Lise: Party politics and prospects for democracy in North Africa / Lise Storm. - Boulder/ Colo. ...: Lynne Rienner Publishers, 2014 - X, 244S., Reg., Anh., Lit. S. 215-234, Lit. Hinw. (Studies on North Africa) ISBN 978-1-58826-958-4

Tocci, Nathalie: Europe, the United States and global human rights governance: the Responsibility to Protect in Libya and Syria / Nathalie Tocci. - o.O.: TRANSWORLD, 2014 - 21S., Lit. S. 16-20 (Transworld Working Paper; 42) 
Tofan, Claudia; Wolf, Willem-Jan van der: Law and war in Syria: a legal account of the crisis in Syria = a legal account of the current crisis in Syria / Claudia Tofan; Willem-Jan van der Wolf. Nijmegen: International Courts Association, 2013 - 640S., Kt., Tab., Anh. ISBN 978-90-5887-059-9

Towards an intellectual and political understanding of the question of religion and the state/ Ghassan Ben Jeddou. - In: Contemporary Arab Affairs (London ...), 7 (January-March 2014) 1. S. 82-114, Lit. Hinw. S. 114

Uddin, Asma T.: Blasphemy laws in Muslim-majority countries / by Asma T. Uddin. - In: The Review of Faith \& International Affairs (Arlington/Va.), 9 (Summer 2011) 2. S. 47-55, Lit. Hinw.

Urech, Luca: Challenging history: the power of transitional justice in Tunisia / by Luca Urech. - In: Al Nakhlah (Medford/Mass.), (June 10, 2014), ca. 18 S.

Valter, Stéphane: La justice chariatique en Syrie "libérée": un modèle juridique consensuel? / Stéphane Valter. - In: Confluences Méditerranée (Paris), (été 2014) 90. S. 155-174

Whidden, James: Monarchy and modernity in Egypt: politics, Islam and neo-colonialism between the wars / James Whidden. - London ...: Tauris, 2013 - VIII, 235S., Ill., Reg., Lit. S. 219-226, Lit. Hinw. S. 193-218 - (Library of Middle East History; 29) ISBN 978-1-84885-706-3

Zayani, Mohamed: Civil society and democratic change in the Arab world: promises and impediments / Mohamed Zayani. - In: Comparative Studies of South Asia, Africa and the Middle East (Durham/N.C.), 32 (2012) 3. S. 674-685, Lit. Hinw.

Zöllner, Hans-Bernd: Fetisch Demokratie: der Arabische Frühling, von außen betrachtet / HansBernd Zöllner. - Hamburg: Abera, 2014 - 160S., Reg., Lit. S. 142-148 ISBN 978-3-939876-17-5 